\title{
EFEKTIVITAS CENDAWAN ENDOFIT SEBAGAI PENGENDALI PENYAKIT BLAST PADA TANAMAN PADI (Oryza sativa)
}

\author{
Sopialena $^{1}$, Suyadi ${ }^{1}$, Sofian ${ }^{1}$, Devi Tantiani ${ }^{2}$ dan Aziz Nur Fauzi ${ }^{2}$ \\ ${ }^{1}$ Laboratorium Ilmu Hama Penyakit Tumbuhan Fakultas Pertanian Universitas \\ Mulawarman. \\ ${ }^{2}$ Mahasiswa Progam Studi Pertanian Tropika Basah Fakultas Pertanian Universitas \\ Mulawarman. \\ E-Mail: sopialena88@gmail.com, tantiani.devi@gmail.com
}

\begin{abstract}
ABSTRAK
Efektivitas Cendawan Endofit Sebagai Pengendali Penyakit Blast Pada Tanaman Padi (Oryza sativa). Penelitian dilakukan untuk menentukan: cendawan endofit yang terdapat pada tanaman padi (Oryza sativa); persentase daya hambat cendawan endofit terhadap cendawan Pyricularia oryzae Cav.; dan mekanisme antagonis antara masing-masing cendawan endofit terhadap cendawan Pyricularia oryzae Cav. Penelitian dilakukan di laboratorium terpadu Fakultas Pertanian Universitas Mulawarman, dan sampel tanaman yang terinfeksi serta tanaman sehat dikumpulkan dari Kelurahan Sungai Kapih, Kecamatan Sambutan, Kota Samarinda. Hasil penelitian disusun dalam Rancangan Acak Lengkap (RAL), yang terdiri dari empat sampel dan setiap sampel diulang sebanyak sepuluh kali. Hasil penelitian menunjukkan bahwa cendawan endofit yang terisolasi dari tanaman padi (Oryza sativa) adalah Trichoderma sp., Rhizopus sp., Gliocladium sp. dan Penicillium sp. Kompetisiterbukti secara in vitro sebagai mekanisme antagonis Rhizopus sp., sedangkan antibiosis terbukti secara in vitro sebagai mekanisme Penicillium sp.. Trichoderma sp dan Gliocladium sp terbukti memiliki dua mekanisme antagonis yaitu kompetisi dan parasitisme. Kemampuan cendawan endofit sebagai agen biologis untuk bersaing dengan cendawan $P$. oryzae itu menghasikan perbedaan daya antagonisme, tingkat tertinggi penghambatan terjadi padaP.oryzae vs Gliocladium sp. (78,96\%).
\end{abstract}

Kata kunci : Cendawan endofit, Mekanisme antagonis, Pyricularia oryzae Cav.

\begin{abstract}
Effectiveness of Endophyte Fungi as a Controling of Blast Disease on Paddy (Oryza sativa). The research was conducted to determine: endophyte fungi on paddy plant (Oryza sativa); the antagonistic percentageof endophyte fungi against to Pyricularia oryzae Cav.; and the antagonistic mechanisms between each endophyte fungi to Pyricularia oryzae Cav..The experiment was conducted at the Integrated Laboratory of Agriculture Faculty of Mulawarman University, and samples of infected plant was collected from Sungai Kapih village, Sambutan Sub-district of Samarinda City The experimental treatments was arranged in a Completely Randomized Design (CRD), consisting of four treatments and each treatment was repeated ten times.The results showed that endophyte fungi isolated from the paddy plant (Oryza sativa) were Trichoderma sp., Rhizopus sp., Gliocladium sp., and Penicillium sp. The competition was proved as the antagonistic mechanism of Rhizopus sp. against, while antibiosis was proved as the antagonistic mechanism of Penicillium sp. against. Trichoderma sp. and Gliocladium sp. against were shown to have two antagonistic mecanism are competition and parasitsm. The capability of endophyte fungi as a biological agents to compete those P. Oryzae was express an antagonism capacity differences, the highest rate of inhibition was occurred on the P. oryzae vs Gliocladium sp. (78,96\%).
\end{abstract}

Key words : Antagonistic mechanim, Endophyte fungi, Pyricularia oryza Cav. 


\section{PENDAHULUAN}

Tanaman padi (Oryza sativa) merupakan komoditi pangan utama di Indonesia, karena padi merupakan makanan pokok bagi warga negara Indonesia. Kebutuhan konsumsi padi terus meningkat seiring dengan bertambahnya jumlah penduduk Indonesia (Widyawati, 2014). Kementerian Pertanian (2014), produksi tanaman padi tahun 2012 produksi padi sebesar 69.056.126 ton, dan pada tahun 2013 meningkat menjadi 71.279.709 ton. Pada tahun 2014 terjadi penurunan produksi padi menjadi 70.831 .752 ton sehingga pada tahun 2014 Indonesia mengimpor beras sebanyak $60.796,8$ ton. Fluktuasi produksi padi di Indonesia terjadi akibat berbagai faktor. Salah satu faktor yang menghambat peningkatan produktivitas padi adalah penyakit yang menyebabkan terjadinya penurunan produksi baik kualitas maupun kuantitas.

Petani umumnya menggunakan pestisida secara berlebihan dalam pengendalian penyakit tanaman tanpa memperhatikan musuh alami yang ada di sekitar pertanaman. Penggunaan pestisida dilakukan tanpa memperhitungkan kerusakan yang ditimbulkan seperti terjadinya resistensi hama terhadap pestisida, resurjensi hama serta matinya musuh-musuh alami, merusak kesehatan manusia dan lingkungan, adanya residu pada produk pertanian, munculnya biotipe baru yang lebih resisten, dan matinya biota penyusun habitat ekologi yang bukan sasaran (Kartohardjono, 2011).

Pengendalian dengan menggunakan pestisida sintetik terbukti merugikan bagi manusia dan lingkungan agroekosistem. Pengendalian ramah lingkungan menjadi jawaban dari persoalan pestisida sintetik ini, banyak bahan alami yang dapat dijadikan sebagai bahan baku dalam pembuatan pestisida hayati. Salah satu bahan baku yang potensial dalam pengendalian dengan menggunakan pestisida hayati yaitu cendawan endofit (Sopialena, 2018). Menurut Sopialena, dkk. (2020) cendawan endofit pada tanaman padi mampu menjadi agensia hayati pengendali hama dan penyakit pada tanaman. Beberapa studi tentang cendawan endofit yang berpotensi sebagai pengendalian hayati telah banyak dilakukan, namun tidak banyak penelitian terkait pengaruh asosiasi cendawan endofit terhadap ketahanan tanaman. Oleh karena itu, penelitian terkait peningkatan ketahanan tanaman dengan asosiasi cendawan endofit dapat memberikan informasi serta alternatif penggunaan pestisida sintetik menjadi pestisida hayati.

\section{METODA PENELITIAN}

\subsection{Tempat dan Waktu}

Penelitian ini dilaksanakan di Laboratorium Ilmu Hama dan Penyakit Tumbuhan Gedung Laboratorium Terpadu Fakultas Pertanian Universitas Mulawarman dan pengambilan tanaman terinfeksi dan tanaman sehat berlokasi di Kelurahan Sungai Kapih Kecamatan Sambutan Kota Samarinda.

\subsection{Metode}

Penelitian dilakukan melalui tahap isolasi, identifikasi, dan uji antagonism cendawan endofit terhadap cendawan patogen Pyricularia oryzae Cav. Pengambilan sampel untuk cendawan patogen penyebab penyakit dilakukan pada tanaman padi yang memperlihatkan gejala penyakit blast secara acak. Pengambilan cendawan endofit dari lokasi penelitian dengan cara mengambil sampel tanaman sehat pada bagian daun atau batang tanaman. 


\section{Isolasi Cendawan Endofit dan Cendawan Patogen}

Isolasi cendawan endofit maupun cendawan patogen dilakukan dengan mengambil bagian tanaman yang sehat dan bagian tanaman yang menunjukan gejala penyakit blast yang disebabkan oleh cendawan Pyricularia oryzae Cav.. Bagian tanaman tersebut kemudian dipotong persegi empat yang terdiri dari jaringan yang sakit dan jaringan yang sehat dengan ukuran kurang lebih 1 x $1 \mathrm{~cm}$. Kemudian potongan tersebut dibersihkan dengan alkohol $70 \%$ dengan cara dicelupkan ke dalam alkohol kemudian dibilas dengan air dan dikeringkan di atas tisue bersih. Selanjutnya dimasukan kedalam cawan petri yang telah berisi media PDA yang telah ditambahkan ekstrak yeast dan chloram penicol, pada isolasi cendawan Pyricularia oryzae Cav. media PDA ditambahkan ekstrak padi atau quacker oats.. Kegiatan isolasi ini dilakukan di dalam LAF. Cawan petri dibungkus dengan kertas untuk mencegah terjadinya kontaminasi kemudian diinkubasi dalam inkubator. Pengamatan dilakukan setiap hari setelah isolasi.

\section{Identifikasi Cendawan Endofit dan Patogen}

Setelah dilakukan isolasi dengan media PDA pada cawan petri dan menunggu selama 3 hari. Kemudian cendawan yang tumbuh di murnikan dan diamati. Sampel koloni dipisahkan dan kemudian diberikan cairan methilene blue dan selanjutnya diamati dengan menggunakan mikroskop. Identifikasi makroskopis meliputi warna koloni, bentuk dan tekstur koloni. Identifikasi mikroskopis meliputi bentuk hifa, jenis hifa, warna konidia dan bentuk konidiofor.

\section{Pemurnian Cendawan}

Dilakukan dari hasil isolasi sebelumnya. Setelah melakukan isolasi dilakukan pemurnian dengan mengambil bahan isolat berupa hifa cendawan saja, dengan menggunakan jarum ose kemudian diletakkan pada cawan petri yang berisi media PDA yang baru. Cawan petri ditutup dan dibungkus dengan plastik cling wrap.

\section{Uji Antagonisme}

Tahap pertama yang dilakukan dalam pengujian adalah meletakkan masing-masing isolat Pyricularia oryzae Cav. dan cendawan endofit secara berpasangan yaitu dengan cara biakan isolat Pyricularia oryzae Cav. dan cendawan endofit yang telah dimurnikan diletakkan pada media PDA dalam cawan petri berdiameter $9 \mathrm{~cm}$ secara berhadapan pada jarak 3 $\mathrm{cm}$ dari tepi cawan petri. Pengamatan dilakukan setiap hari setelah isolasi dengan pengukuran daya hambatan pertumbuhan cendawan tersebut, kemudian dihitung presentase penghambatnya. Perhitungan daya hambatan dilakukan dengan menggunakan rumus (Dwiastuti dkk., 2016). 


$$
l=\frac{r 1-r 2}{r 1} \times 100 \%
$$

Keterangan :

$l=$ Presentase penghambatan

$\mathrm{r} 1$ = Jari-jari koloni B yang tumbuh ke arah berlawanan dengan antagonis A

r2 = Jari-jari koloni B yang tumbuh ke arah antagonis A

\section{HASIL PENELITIAN DAN PEMBAHASAN}

\section{Cendawan Pyricularia oryzae Cav.}

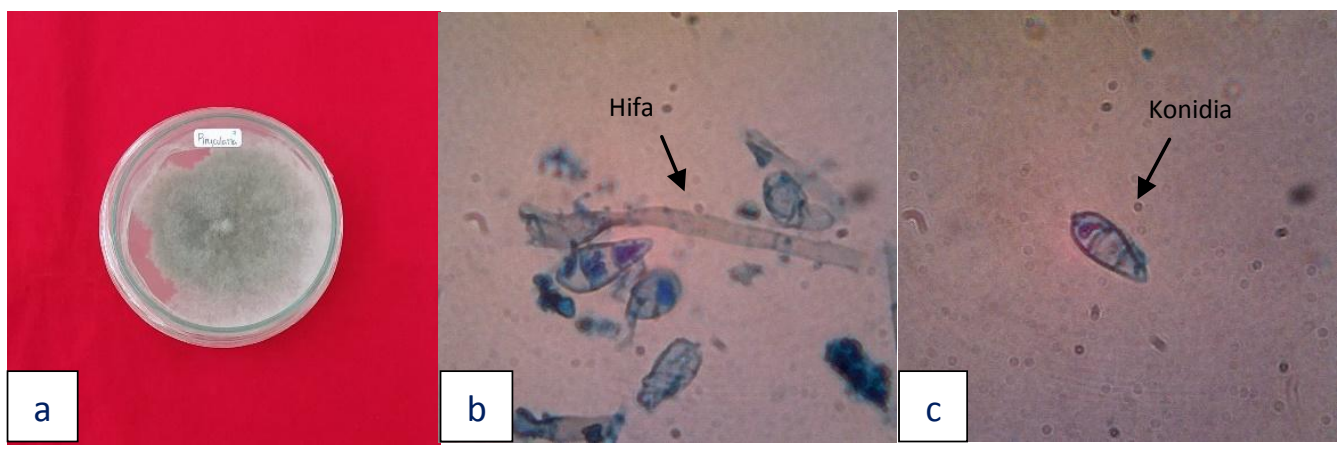

Gambar 1. a. Koloni Pyricularia oryzae Cav., b. Hifa Pyricularia oryzae Cav. (400x), c. Konidia Pyricularia oryzae Cav.(400x)

Pyricularia oryzae Cav. pada media PDA sangat sulit dibiakkan, oleh karena itu media yang digunakan merupakan media khusus dengan penambahan ekstrak yeast dan oatmeal sebagai bahan tambahan nutrisi bagi cendawan tersebut. Secara visual, Pyricularia oryzae Cav. yang tumbuh pada media PDA memiliki warna putih kehitaman dengan bentuk bulat dan menyerupai kapas. Dari hasil pengamatan yang dilakukan maka hal ini sesuai dengan pendapat yang dikemukakan oleh Batubara (2017) bahwa pada tanaman yang terinfeksi cendawan Pyricularia oryzae Cav. akan memiliki miselium yang berwarna putih dan berbentuk seperti kapas yang dapat menyebabkan lesi nekrotik berwarna abu atau kecoklatan.

Ciri mikroskopis Pyricularia oryzae Cav. memiliki konidia yang berbentuk seperti buah pear dengan tiga septa, hifa yang dimiliki cendawan ini bersekat. Hal ini di jelaskan pula pada buku Barnett and Hunter ( 1972) bahwa hifa yang dimiliki Pyricularia oryzae Cav. bersekat dengan konidia yang berbentuk oval memanjang serta berwarna hialin. 


\section{Cendawan Endofit \\ Trichoderma sp.}

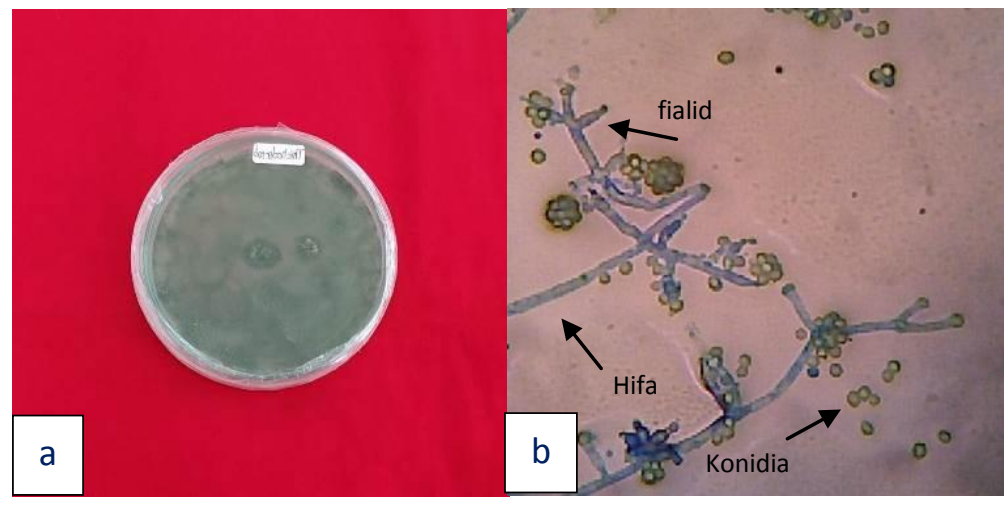

Gambar 2. a. Koloni Trichoderma sp., b. Hifa, fialid dan konidia Trichoderma sp. (400x)

Trichoderma sp. pada media PDA secara visual memiliki warna hijau tua dengan bentuk seperti lingkaran dan arah pertumbuhan yang menyebar ke segala arah, cendawan ini memiliki tekstur seperti kapas (Sopialena dkk., 2018). Hal ini sesuai dengan pendapat yang dideskripsikan oleh Suanda (2019) bahwa Trichoderma sp. memiliki koloni dengan permukaan yang datar berbentuk bulat, mulanya cendawan ini berwarna putih dan pada bagian tengah berwarna hijau muda lalu pada saat 6 hari setelah isolasi cendawan ini berubah berwarna hijau tua pada seluruh permukaan.

Ciri mikroskopis dari Trichoderma sp. yaitu memiliki konidia yang berbentuk bulat, hifa yang dimiliki cendawan ini tidak bersekat dan berdinding halus, memiliki percabangan hifa yang menyerupai piramid dengan fialid yang tersusun pada kelompok berbeda antara 2-3 fialid per kelompok. Hal ini juga dikemukakan oleh Ristiari dkk. (2019) bahwa Trichoderma sp. memiliki dinding hifa yang halus dan membentuk percabangan serta memiliki fialid yang tersusun.

\section{Rhizopus sp.}

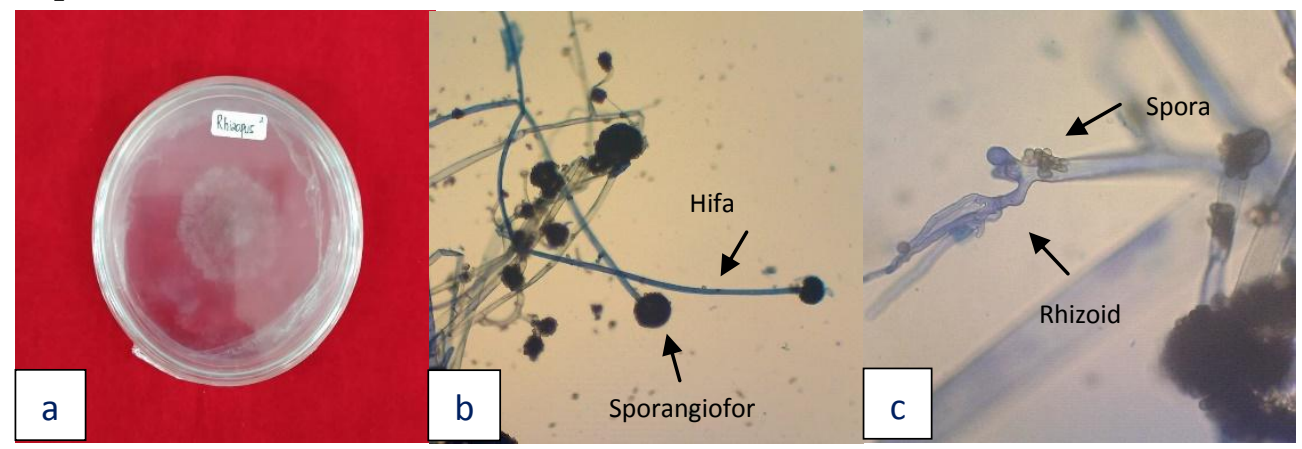

Gambar 3. a. Koloni Rhizopus sp., b. Hifa dan sporangiofor Rhizopus sp. (400x), c. Rhizoid dan spora Rhizopus sp. (400x)

Secara visual cendawan Rhizopus sp. memiliki warna koloni putih kehitaman dengan bentuk koloni bulat dan seperti kapas tipis. Hal ini sesuai dengan pernyataan yang di ungkapkan oleh Sulistiyono dan Mahyni (2019) bahwa Rhizopus oryzae memiliki koloni berwarna keputihan dan menjadi abu-abu dengan bertambahnya waktu.

Ciri mikroskopis Rhizopus sp. yaitu 
memiliki hifa yang tidak bersekat, bercabang dan berjalin membentuk miselium, dinding sel yang tersusun dari kitin, memiliki rhizoid yang tumbuh secara berlawanan dan terletak pada posisi yang sama dengan sporangiofor, spora yang dimiliki jamur ini berbentuk bulat. Hal ini dijelaskan oleh Barnett dan Hunter (1972) bahwa Rhizopus sp. memiliki hifa yang tidak bersekat dan sporangium berbentuk bulat pada ujung hifa, memiliki rhizoid dan bentuk spora yang bulat.

\section{Gliocladium sp.}

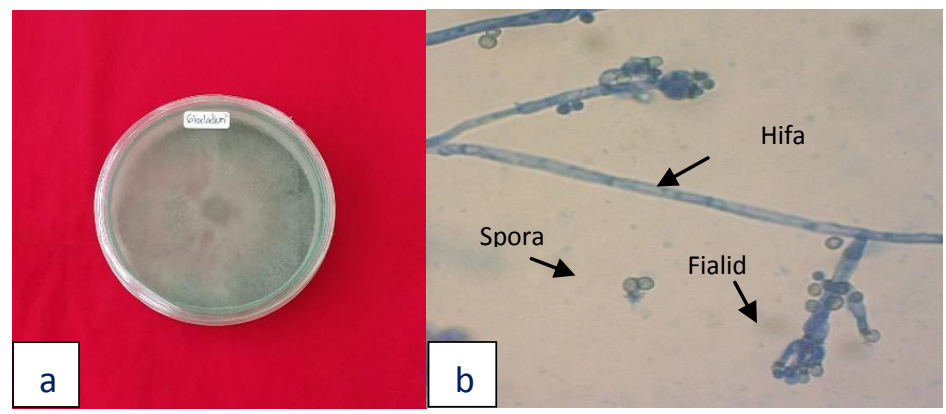

Gambar 4. a. Koloni Gliocladium sp., b. Hifa, fialid dan spora Gliocladium sp. (400x)

Secara visual cendawan Gliocladium sp. memiliki koloni yang berwarna hijau tua kekuningan dengan tekstur miselium yang agak tipis seprti beludru dan memiliki daya tumbuh yang cepat. Hal ini sesuai dengan pernyataan Ruliyanti dan Majid (2020) bahwa cendawan ini melalui pengamatan makroskopis berwarna putih yang kemudian akan berwarna hijau muda hampir kekuningan dengan miselium yang tipis seperti bludru.

Ciri mikroskopis Gliocladium sp. yaitu memiliki hifa yang bersekat dengan konidofor tegak, fialid membentuk kelompok pada ujung konidiofor dan spora berbentuk bulat. Menurut Ruliyanti dan Majid (2020) cendawan Gliocladium sp. memiliki hifa bersekat dengan konidiofor yang tegak dan bercabang, spora yang dihasilkan berbentuk bulat.

\section{Penicillium sp.}

Secara visual cendawan Penicillium sp. memiliki warna koloni putih kunung keabuan sampai kehijauan dengan tekstur seperti bludru. Hal ini sesuai dengan pendapat Anggraeni dan Usman (2015) yaitu koloni Penicillium sp. memiliki warna abu-abu kehijauan dengan tekstur seperti bludru, wol atau kapas.

Cendawan Penicillium sp. secara mikroskopis akan terlihat memiliki hifa yang tidak bersekat dan bercabang, fialid membentuk susunan kelompok yang khas seperti sikat dengan konidia yang terjalin sepeti rantai, cendawan ini memiliki spora berbentuk bulat. Hal ini juga dijelaskan pada buku Barnett dan Hunter (1972) bahwa Penicillium sp. memiliki hifa yang hialin dengan konidia bulat, konidiofor muncul tegak dari miselium dan bercabang pada ujungnya yang membentuk sekelompok fialid. 


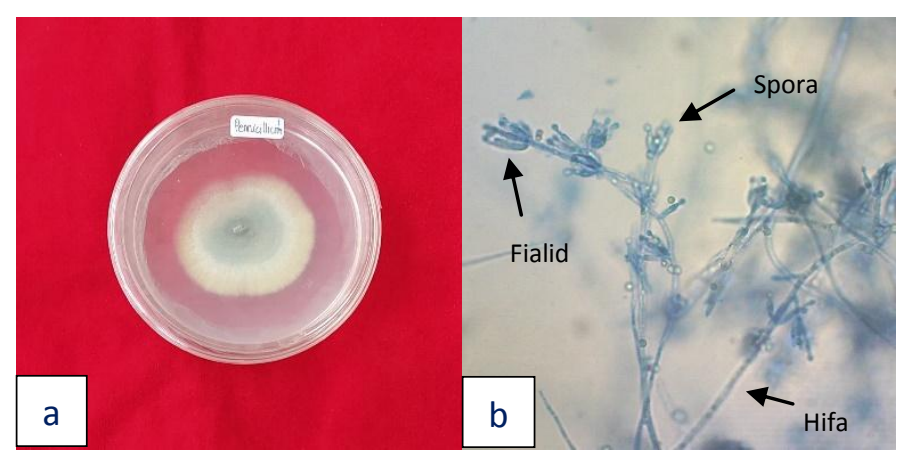

Gambar 5. a. Koloni Penicillium sp., b. Hifa, fialid dan spora Penicillium sp. (400x)

\section{Laju Pertumbuhan Cendawan Endofit dan Pyricularia oryzae Cav.}

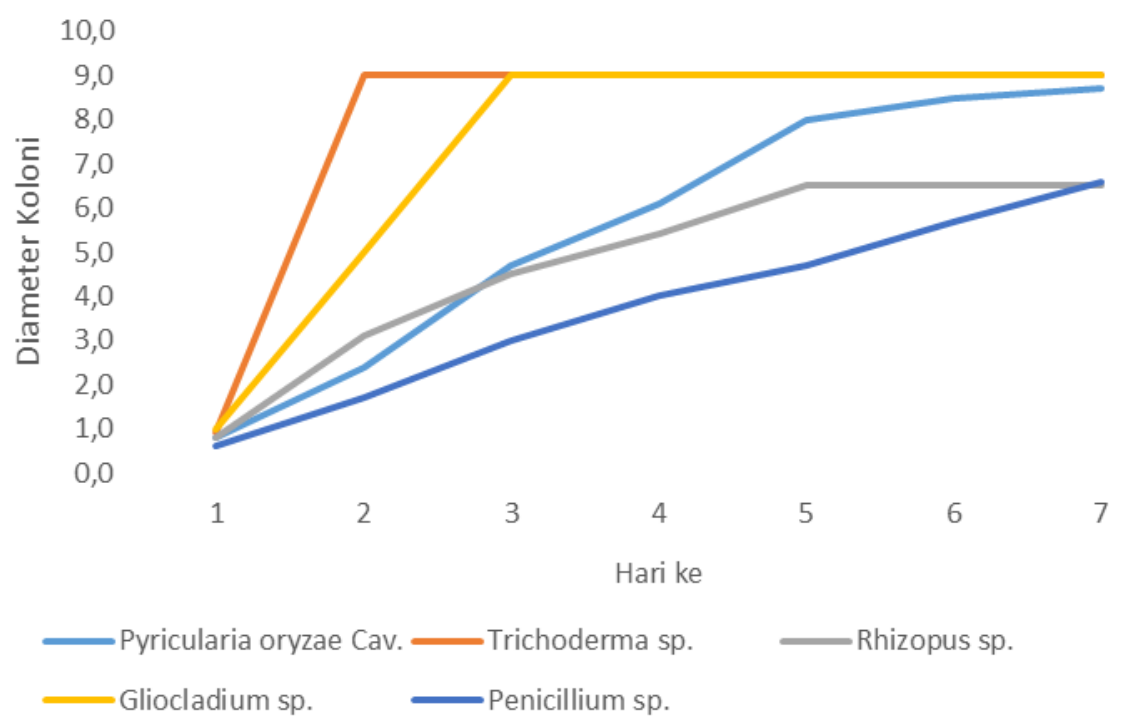

Gambar 6. Grafik Laju Pertumbuhan Cendawan

Berdasarkan hasil pengamatan yang telah dilakukan terhadap diameter masing-masing cendawan menunjukkan bahwa diameter koloni cendawan mengalami pertumbuhan yang terhitung hingga hari ke 7 , pertumbuhan yang paling signifikan terjadi pada cendawan Gliocladium sp. dan Trichoderma sp. karena pada hari kedua dan ketiga telah memenuhi seluruh cawan. Pada cendawan patogen Pyricularia oryzae Cav. pertumbuhan koloni tergolong lebih cepat dibandingkan cendawan Rhizopus sp. dan Penicillium sp.. Menurut Fitriani dkk. (2019) pada umumnya suatu koloni berasal dari satu sel yang mengalami pertambahan volume yang bersifat tetap atau tidak bisa kembali ke volume sebelumnya dengan memperbanyak spora atau konidia. Pertumbuhan cendawan dipengaruhi oleh kemampuan cendawan tersebut dalam menghasilkan spora, semakin tinggi kerapatan spora yang dihasilkan maka semakin tinggi pula tingkat pertumbuhan koloni cendawan tersebut (Sopialena dkk., 2019). 
Pada pengamatan secara makroskopis masing-masing diameter cendawan didapatkan hasil bahwa cendawan Trichoderma sp. mengalami laju pertumbuhan maksimal pada hari ke2 sebesar $9 \mathrm{~cm}$, cendawan Gliocladium sp. mengalami laju pertumbuhan maksimal pada hari ke-3 sebesar $9 \mathrm{~cm}$, cendawan Penicillium sp. mengalami pertumbuhan yang stabil dan pada hari ke-7 mencapai diameter 6,6 cm, cendawan Rhizopus sp. dengan laju pertumbuhan yang agak lambat pada hari ke-7 mencapai diameter 6,5 cm. Cendawan patogen Pyricularia oryzae
Cav. mengalami laju pertumbuhan yang lebih baik dibandingkan Penicillium sp. dan Rhizopus sp. karena pada hari ke-7 mencapai diameter $8,7 \mathrm{~cm}$.

Pertumbuhan cendawan dipengaruhi oleh beberapa faktor seperti substrat, cahaya, kelembaban, suhu dan senayawa-senyawa kimia yang terdapat pada lingkungan sekitarnya. Substrat merupakan sumber nutrisi yang dimanfaatkan untuk mengekskresi enzim, cahaya dapat mempengaruhi pertumbuhan spora pada cendawan. Cendawan dapat tumbuh pada cepat pada kelembaban yang tinggi sekitar $90 \%$.

\section{Kerapatan Spora}

Tabel 1. Kerapatan Spora Isolat Cendawan Endofit

\begin{tabular}{cc}
\hline Nama & Kerapatan Spora \\
\hline Trichoderma sp. & $138,4 \times 10^{4}$ \\
Rhizopus sp. & $35,2 \times 10^{4}$ \\
Gliocladium $\mathrm{sp}$. & $121,6 \times 10^{4}$ \\
Penicillium $\mathrm{sp}$. & $88 \times 10^{4}$ \\
\hline
\end{tabular}

Kerapatan spora cendawan endofit menunjukkan tingkat virulensi atau efektivitas cendawan tersebut sebagai agen hayati. Pada cendawan Trichoderma sp. didapatkan hasil kerapatan spora sebesar $138,4 \times 10^{4}$ spora $\mathrm{ml}^{-1}$. Pada cendawan Gliocladium sp. didapatkan hasil kerapatan spora sebesar 121,6 x 10 spora $\mathrm{ml}^{-1}$, cendawan Penicillium sp. menghasilkan spora sebesar $88 \times 10^{4}$ spora $\mathrm{ml}^{-1}$ dan cendawan Rhizopus $\mathrm{sp}$. menghasilkan spora sebesar 35,2 x $10^{4}$ spora $\mathrm{ml}^{-1}$. Mekanisme penekanan cendawan endofit terhadap cendawan patogen dipengaruhi oleh sifat cendawan tersebut dalam menghasilkan spora yang melimpah, hal ini dapat terjadi apabila keadaan lingkungan nya sesuai yaitu dengan suhu $25^{\circ}-30^{\circ} \mathrm{C}$ dan kelembaban diatas $90 \%$.

Tingginya kerapatan spora tidak menunjukkan efektivitas daya hambat yang tinggi pula, karena pada setiap cendawan endofit memiliki kandungan enzim yang berbeda bahkan pada satu genus cendawan memiliki kandungan enzim yang berbeda. Menurut Ristiari dkk. (2019) pada Trichoderma sp. setiap spesies mampu menghasilkan salah satu atau lebih enzim litik, glukanase, selulase, kitinase dan antibiotik antifungal, pada Gliocladium sp. mampu menghasilkan senyawa gliovirin dan viridin (Risthayeni \& Zahara, 2018). Menurut Purwantisari (2018) Penicillium sp. dikenal sangat mampu menghambat pertumbuhan bakteri karena memiliki senyawa antibakteri penisilin dan pada Rhizopus sp. mampu menghasilkan mikotoksin, enzim dan antibiotika (Indrawati dkk., 2019). 


\section{Uji Daya Hambat}

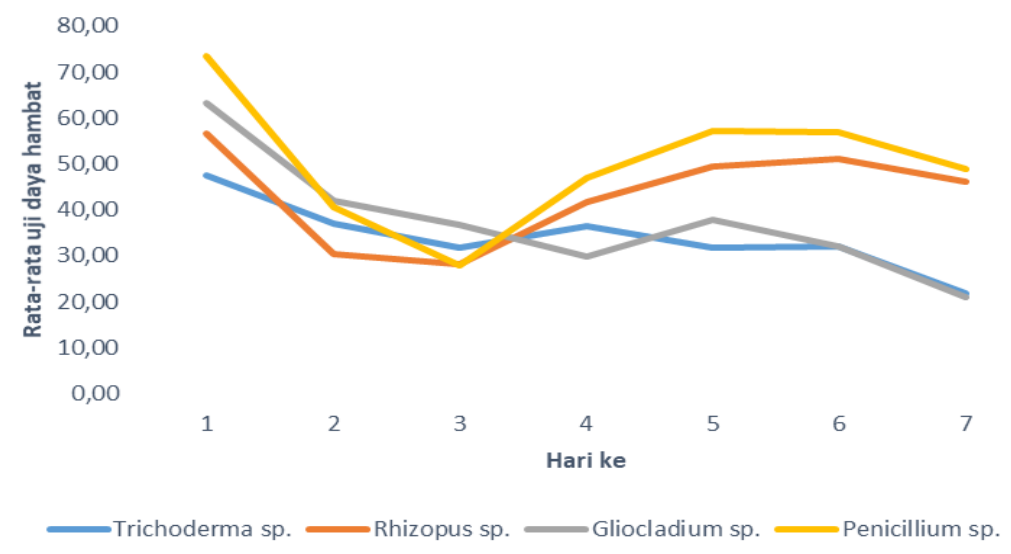

Gambar 7. Grafik Rata-Rata Uji Daya Hambat

Hasil sidik ragam pada uji daya hambat dengan uji lanjut BNT 5\% Pyricularia oryzae Cav. terhadap cendawan endofit terlihat bahwa pada hari ke-1 sampai dengan hari ke-4 tidak satupun cendawan endofit menunjukkan penekan yang nyata terhadap Pyricularia oryzae Cav.. Pada hari ke-5 perlakuan $P$. oryzae vs Trichoderma sp. tidak berbeda nyata terhadap perlakuan $P$. oryzae vs Gliocladium sp., namun berbeda nyata terhadap perlakuan P.oryzae vs Rhizopus sp. dan P. oryzae vs Penicillium sp.. Dimana perlakuan dengan penekanan tertinggi pada cendawan patogen yaitu Trichoderma sp. sebesar 68,19 \%, lalu Gliocladium sp. sebesar 62,13\%, Rhizopus sp. sebesar 50,6\% dan Penicillium sp. sebesar 42,82\%.

Pada hari ke-6 perlakuan $P$. oryzae vs Trichoderma sp. tidak berbeda nyata terhadap perlakuan $P$. oryzae vs Gliocladium sp., namun berbeda nyata terhadap perlakuan P.oryzae vs Rhizopus sp. dan P. oryzae vs Penicillium sp.. Dimana perlakuan dengan penekanan tertinggi pada cendawan patogen yaitu Trichoderma sp. sebesar 68,01 \%, lalu Gliocladium sp. sebesar 67,93\%, Rhizopus sp. sebesar $49 \%$ dan Penicillium sebesar 43,22 \%. Pada hari ke-6 persentase hambatan mengalami penurunan dikarenakan virulensi dari cendawan patogen masih dapat berkembang.

Pada hari ke-6 perlakuan $P$. oryzae vs Gliocladium sp. tidak berbeda nyata terhadap perlakuan $P$. oryzae vs Trichoderma sp., namun berbeda nyata terhadap perlakuan P.oryzae vs Rhizopus sp. dan $P$. oryzae vs Penicillium sp.. Dimana perlakuan dengan penekanan tertinggi pada cendawan patogen yaitu Gliocladium sp. sebesar 78,96 \%, lalu Trichoderma sp. sebesar 78,08\%, Rhizopus sp. sebesar $53,97 \%$ dan Penicillium sebesar 51,15\%.

Dari hasil pengujian daya hambat membuktikan bahwa kerapatan spora tidak mempengaruhi daya hambat, namun laju pertumbuhan dan kandungan enzim pada cendawan endofit mempengaruhi daya hambat cendawan endofit terhadap $P$. oryzae. Cendawan Gliocladium sp. menjadi yang paling tinggi daya hambatnya karena memiliki laju pertumbuhan yang sangat cepat, jumlah spora yang dihasilkan juga mampu menghambat pertumbuhan cendawan patogen serta cendawan ini menghasilkan senyawa gliovirin dan viridin yang mampu menekan dan menghambat pertumbuhan cendawan patogen. Hal ini sesuai dengan pernyataan Risthayeni dan 
Zahara (2018) yaitu cendawan Gliocladium sp. memiliki daya hambat yang cukup tinggi terhadap cendawan patogen karena senyawa yang dihasilkan merupakan toksin atau antifungal bagi cendawan patogen.

\section{Jenis Antagonis}

Mekanisme antagonis cendawan endofit terhadap cendawan patogen Pyricularia oryzae Cav. yaitu kompetisi, antibiosis dan parasitisme. Jenis antagonis kompetisi diperoleh dari hasil pengamatan pada P.oryzae vs Rhizopus sp., mekanisme antagonis kompetisi dan parasitisme diperoleh dari hasil pengamatan P.oryzae vs Trichoderma sp. dan P.oryzae vs Gliocladium sp., sedangkan mekanisme antagonis antibiosis diperoleh dari hasil pengamatan P.oryzae vs Penicillium sp. Hal ini sesuai dengan pernyataan Octriana (2016) bahwa Trichoderma sp. dan Gliocladium sp. mengantagonis cendawan Phytium sp. dengan jenis antagonis kompetisi dan parasitisme, sedangkan cendawan Penicillium sp. mengantagonis cendawan patogen dengan jenis antagonis antibiosis.

Pengamatan mekanisme antagonis cendawan endofit terhadap $\mathrm{P}$. oryzae dilakukan pada hari ke-7. Mekanisme antagonis yang terjadi pada masingmasing perlakuan dapat dilihat pada tabel 2 dan gambar 8

Tabel 2. Mekanisme antagonis cendawan endofit

\begin{tabular}{lccc}
\hline Perlakuan & Kompetisi & Antibiosis & Parasitisme \\
\hline P.oryzae vs Tricho & + & - & + \\
P.oryzae vs Rhizopus & + & - & - \\
P.oryzae vs Gliocladium & + & - & + \\
P.oryzae vs Penicillium & - & + & - \\
\hline
\end{tabular}

Keterangan : (+) terjadi mekanisme antagonis, (-) tidak terjadi mekanisme antagonis

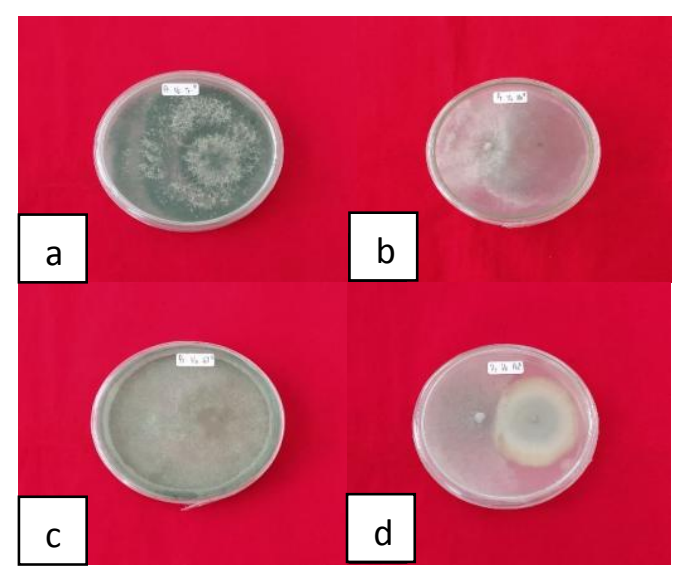

Gambar 8. (a) Mekanisme antagonis P.oryzae vs Trichoderma sp. (b) Mekanisme antagonis P.oryzae vs Rhizopus sp. (c) Mekanisme antagonis P.oryzae vs Gliocladium sp. (d) Mekanisme antagonis P.oryzae vs Penicillium sp. 


\section{KESIMPULAN}

Berdasarkan hasil pengamatan penelitian dapat diambil kesimpulan sebagai berikut : cendawan endofit yang terisolasi dari tanaman padi (Oryza sativa) adalah Trichoderma sp., Rhizopus sp., Gliocladium sp. dan Penicillium sp. Kompetisi terbukti secara in vitro sebagai mekanisme antagonis Rhizopus sp., sedangkan antibiosis terbukti secara in vitro sebagai mekanisme Penicillium sp.. Trichoderma sp dan Gliocladium sp terbukti memiliki dua mekanisme antagonis yaitu kompetisi dan parasitisme. Kemampuan cendawan endofit sebagai agen biologis untuk bersaing dengan cendawan $P$. oryzae itu menghasikan perbedaan daya antagonisme, tingkat tertinggi penghambatan terjadi pada P.oryzae vs Gliocladium sp. $(78,96 \%)$.

\section{DAFTAR PUSTAKA}

Anggraeni, D. N., \& Usman, M. (2015). Uji Aktivitas dan Identifikasi Jamur Rhizosfer pada Tanah Perakaran Tanaman Pisang (Musa paradisiaca) Terhadap Jamur Fusarium. BIOLINK (Jurnal Biologi Lingkungan Industri Kesehatan), 1(2), 89-98. doi:10.19184/jph.v3i1.17147.

Batubara, U. M., Suparjo, S., Maritsa, H., Tari, N. F., \& Andriani, S. (2017). Efektivitas Bakteri Amilolitik Asal Geopark Merangin Jambi terhadap Patogenitas Jamur Pyricularia oryzae Penyebab Penyakit Blas Daun Padi. BIO-SITE | Biologi dan Sains Terapan, 3(1), 6-11.

Barnett, H. L., \& Hunter, B. B. (1972). Illustrated genera of imperfect fungi. Illustrated genera of imperfect fungi. Mycologia.doi: $10.2307 / 3757954$.

Dwiastuti, M. E., Fajri, M. N., \& Yunimar, Y. (2016). Potensi Trichoderma spp. sebagai Agens Pengendali Fusarium spp. Penyebab Penyakit Layu pada Tanaman Stroberi. Jurnal Hortikultura, 25(4), 331-339. doi:10.21082/jhort.v25n4.

Fitriani, M. L., Wiyono, S., \& Sinaga, M. S. (2019). Potensi Kolonisasi Mikoriza Arbuskular dan Cendawan Endofit untuk Pengendalian Layu Fusarium pada Bawang Merah. Jurnal Fitopatologi Indonesia, 15(6), 228238. doi:10.14692/jfi.15.6.228-238.

Indrawati, A., Hartih, N. A., \& Muyassara, M. (2019). Isolasi Dan Uji Potensi Fungi Endofit Kulit Batang Langsat (Lansium domesticum Corr.) Penghasil Antibakteri Terhadap Staphylococcus aureus dan Escherichia coli. Media Farmasi, 15(1), 36-42.

Kartohardjono, A. (2011). Penggunaan musuh alami sebagai komponen pengendalian hama padi berbasis ekologi. Pengembangan Inovasi Pertanian, 4(1), 29-46.

Kementerian Pertanian. (2014). Statistik produksi hortikultura tahun 2014. Stat. Produk Hortik. Tahun 2014.

Octriana, L. (2016). Potensi agen hayati dalam menghambat pertumbuhan Phytium sp. secara in vitro. Buletin Plasma Nutfah, 17(2), 138-142. Doi:10.21082/blpn.v17n2.2011.p13 8-142.

Purwantisari, S. (2018). Kemampuan Antagonisme Pseudomonas sp. dan Penicillium sp. Terhadap Cercospora nicotianae In Vitro. 
Jurnal Akademika Biologi, 7(3), 17.

Risthayeni, P., \& Zahara, F. (2018). Uji Efektifitas Jamur Antagonis Trichoderma sp. dan Gliocladium sp. Untuk Mengendalikan Penyakit Pokahbung (Fusarium moniliforme) PadaTanaman Tebu (Saccharum officinarum): The effectivity of Trichoderma sp and Gliocladium sp. to control the Pokahbung disease (Fusarium moniliforme) on sugarcane (Saccharum officinarum). Jurnal Online Agroekoteknologi, 6(2), 339-344.

Ristiari, N. P. N., Julyasih, K. S. M., \& Suryanti, I. A. P. (2019). Isolasi Dan Identifikasi Jamur Mikroskopis Pada Rizosfer Tanaman Jeruk Siam (Citrus nobilis Lour.) Di Kecamatan Kintamani, Bali. Jurnal Pendidikan Biologi undiksha, 6(1), 10-19.

Ruliyanti, W., \& Majid, A. (2020). Pengaruh Pemberian Vermikompos pada Media Tanam Terhadap Efektivitas Gliocladium sp. dalam Mengendalikan Penyakit Layu Fusarium (Fusarium oxysporum) pada Tanaman Semangka (Citrulus vulgaris, Schard). Jurnal Pengendalian Hayati, 3(1), 14-21. doi:10.19184/jph.v3i1.17147.

Sopialena, S., Suyadi, S., Sahil, M., \& Nurdiana, J. (2018). The diversity of endophytic fungi associated with Piper nigrum in the tropical areas: A recent study from Kutai
Kartanegara, Indonesia. Biodiversitas Journal of Biological Diversity, 19(6), 2028-2034. doi:10.13057/biodiv/d190607

Sopialena, S. (2018). Pengendalian Hayati dengan memberdayakan potensi mikroba. in Pengendalian Hayati dengan Memberdayakan Potensi Mikroba. p.104.

Sopialena, S., Sofian, S., \& Allita, L. D. (2019). Diversitas Jamur Endofit Pada Tanaman Padi (Oryza sativa L.) dan Potensinya Sebagai Pengendali Hama. Jurnal Agroekoteknologi Tropika Lembab, 2(1), 44-49. doi:10.35941/JATL.

Suanda, I. W. (2019). Karakterisasi Morfologis Trichoderma sp. Isolat JB Dan Daya Hambatnya Terhadap Jamur Fusarium sp. Penyebab Penyakit Layu Dan Jamur Akar Putih Pada Beberapa Tanaman. Jurnal Widya Biologi, 10(02), 99112. doi: 10.1017/CBO9781107415324.004.

Sulistiyono, F. D., \& Mahyuni, S. (2019). Isolasi Dan Identifikasi Jamur Endofit Pada Umbi Talas (Colocasia esculenta (L.) Schoot). Jurnal Sains Natural, 9(2), 66-70. doi:10.31938/jsn.v9i2.235

Widyawati, W., Syafrial, S., \& Mustadjab, M. M. (2014). Dampak kebijakan tarif impor beras terhadap kinerja ekonomi beras di Indonesia. HABITAT, 25(2), 125134. 